\title{
A Brief Biography of António Andrade De Gouveia: An Eminent Portuguese Chemist of the University Of Coimbra
}

\author{
Paulo Nuno Martins* \\ Interuniversity Center for History of Science and Technology, New University of Lisbon, Portugal
}

Submission: May 03, 2018; Published: May 09, 2018

"Corresponding author: Paulo Nuno Martins, Interuniversity Center for History of Science and Technology, New University of Lisbon, Campus of Caparica, Building VII, Floor 2, 2829-516 Caparica, Portugal, Email: paulonunom@gmail.com

\begin{abstract}
António Jorge Andrade de Gouveia was an eminent Portuguese chemist of the XX century. In this short communication, I will describe his life, giving prominence to his work in the area of chemistry.

Keywords: Scholar of organic chemistry at University of Coimbra; Spectrophotometric studies in organic chemistry; History of chemistry; Rector of the University of Coimbra
\end{abstract}

\section{Introduction}

António Jorge Andrade de Gouveia was born in 8th June 1905, in Guarda. He was the son of António Carvalho de Gouveia and Angelina of Soledad Sarah Bette Andrade de Gouveia. He attended the primary school at S. Vicente of Guarda and then he moved to Viseu where he completed his high school studies. From 1922 to 1928, he enrolled in the Faculty of Sciences of the University of Coimbra, where he completed a degree in Physical and Chemical Sciences [1]. From 1927 to 1930, he was assistant of scholar Egas Pinto Basto, having published the article entitled "Determination of mangnesium in Miranda do Corvo" [2]. In 1927, the scholar Egas Pinto Basto proposed him to attend the theoretical chemistry courses of scholars Madame Currie, Jean Perrin, Marquis and, subsequently, from 1931 to 1934, to attend the Research Laboratories of Organic Chemistry and Spectra of University of Liverpool guided by scholars Heilbron and Robertson [3].

In 1934, he awarded a $\mathrm{PhD}$ entitled "Contributions to the study of the role of the double bond in the absorption spectra of organic compounds", in Philosophy by the Chancellor of the University of Liverpool [4] and, in 1941, he got the equivalence of his PhD in Physical and Chemical Sciences at the University of Coimbra. In 1944, he presented a dissertation entitled "Contribution to the study of the Portuguese oleoresins of "Pine Pinaster" and "Pinus Pinea". Spectrophotometric study of resin acids and derivatives" in order to became a scholar of chemistry at the Faculty of Sciences of the University of Coimbra [5].
António Andrade de Gouveia also assumed various management positions, such as member of the NATO (North Atlantic Treaty Organization) at Advanced Study Institute on Protein Structure and Function. He had also an active participation in several scientific societies, such as member of the Institute of Coimbra, member of the Academy of Sciences of Lisbon (later, he became vice-Secretary) and participated in several congresses and scientific meetings with emphasis, in 1934, the meeting on "Chemical Society", in London (Burlington House), in 1940, 1942 and 1950, the Luso-Spanish Congress for the "progress of science", in 1955, the XIV International Congress of Pure and Applied Chemistry, in Zurich, in 1956, XV Congress of the International Union of Pure and Applied Chemistry, in Lisbon, in 1957, XVI International Congress of Pure and Applied Chemistry, in Paris, in 1964, the Conference of Rectors of European Universities, in Göttingen, in 1966, the Congress of the Communities of Portuguese culture, in Mozambique, in 1967, the participation in the V International Colloquium of Luso-Brazilian Studies, in Coimbra, as well as a specialist in Study Missions to Universities and Institutes of Great Britain (Aberystwyth (Biochemical Depatment), Leeds (Department of Food and Leather), Liverpool (Department of Biochemistry), London (Science Research Council)) [6].

From 1935 to 1975, he was also Director of the Chemical Laboratory of the University of Coimbra and then, between 1960 and 1963, he became Director of the Faculty of Sciences of the 
University of Coimbra. In 1962, he was member of the Board of National Education and, between 1963 to 1970, he was Rector of the University of Coimbra. He was also honored with the Grande Ufficialle nell'Ordine Al Mérito della Republica Italiana and Grand Officer of the Order of Santiago. Antonio Andrade de Gouveia died on $13^{\text {th }}$ July 2002, in Santo António dos Olivais, Coimbra [6].

\section{Methods}

In this short communication about António Jorge Andrade de Gouveia, I collected and analyzed the main scientific books and technical articles, in this area of study, that are available in academic libraries. Thus, I selected the 22 most important items, based on the "impact factor" of the article and the "reference" books on this topic in order to be useful to the reader who aims to have just an idea of this subject, maintaining the scientific rigor of my research.

\section{Results and Discussions}

In this section, I will present the results and the most relevant facts of my research about the António Andrade de Gouveia's most important works on chemistry. In fact, the most important part of the work of António Andrade de Gouveia was in the field of organic chemistry. From 1934 to 1960, António de Gouveia was the scholar of the discipline of organic chemistry (theoretical and practical) of the Faculty of Sciences of the University of Coimbra [7]. During this time, he published several articles related to the study of the oleoresines of the pine, the determination of vitamins, amino acids, the dipeptides, quinones, essential oils and various synthetic products with the title "Quantitative determination of vitamin A by the spectrophotometric method. Study of some cod liver oils of Portuguese fishing companies" [8], "Quantitative determinations of vitamin A, ergostrol, vitamin B2 (lactoffavin) and vitamin C by Physical-Chemical methods. Study of the Bairrada red wine" [9], "Quantitative determination of phytic acid. Study of bakery products from Oporto" [10], "Contribution to the chemical study of fish of the Portuguese coast. Carotenoids of the sardine "Pilchardus Walbaum" [11], "Bivalent cobalt complexes with resinous acids. Composition and spectrophotometric study" [12], "Micro-analytical methods of determination of plumbagina and related naphtoquinones, in aqueous solutions and fisiological middle. Differences of behavior with the structure" [13].

As an international scientist, he had a collaboration with the scholar R.A. Morton related with the problem of the relationship between the structure and absorption spectra of organic compounds. He published a number of papers related with this issue, such as "Chromophoric groups-Part I. Ultraviolet absorption spectra of Indene and certain of its derivatives" [14], "Chromophoric groups-Part II. Absorption spectra of naphthalene, hydronaphthalenes and related compounds" [15]. These works were carried out in the Chemical Laboratory of the Faculty of Sciences of the University of Coimbra, Office of visible and ultraviolet spectrophotometry through donations by the funds Sá Pinto and the Portuguese Institute of High Culture.
Furthermore, António Jorge Andrade de Gouveia also published several papers linked to the History and Philosophy of Science, particularly on chemistry, such as "Compliment to Professor Dr. D António Pereira Forjaz" [16], "Vicente de Seabra and the chemical revolution in Portugal" [17], "The paradigms of chemical affinity and the Faculty of Philosophy in the late $18^{\text {th }}$ century" [18], "15 ${ }^{\text {th }}$ and $16^{\text {th }}$ century books on chemical arts and simple drugs, in bookstores of the University of Coimbra and of colleges of Coimbra" [19], "Garcia d'Orta and Amato Lusitano in the science of their time" [20], "Development of chemistry and related sciences and the impact in the cultural and scientific activities in Portugal" [21].

\section{Conclusion}

António Andrade de Gouveia was arguably, an eminent chemist of the $20^{\text {th }}$ century at University of Coimbra. On $1^{\text {st }}$ September 1975, he retired and became a member of the Association of former Students of Coimbra and the Institute of Coimbra, as well as member in several national and international scientific associations. Nowadays, there is an award named by "Professor Andrade de Gouveia" that is attributed to the best student of the Master's degree in chemistry from the University of Coimbra [22].

\section{References}

1. Manuel Rodrigues, Abílio Queirós, Luís de Almeida (1992) Memoria Professorum Universitatis Conimbrigensis, Arquivo da Universidade de Coimbra.

2. António de Gouveia (1930) Dosagem do manganésio numa rocha de Miranda do Corvo, Revista de Química Pura e Aplicada, Serie III, Year V, №1.

3. Manuel Rodrigues, Abílio Queirós, Luís de Almeida (1992) Memoria Professorum Universitatis Conimbrigensis, Arquivo da Universidade de Coimbra.

4. António de Gouveia (1934) Contributions to the study of the role of the double bond in the absorption spectra of organic compounds, $\mathrm{PhD}$ Thesis, University of Liverpool.

5. António Andrade de Gouveia (1943) Contribuição para o estudo das oleorresinas portuguesas do Pinus Pinaster e do Pinus Pinea. Estudo espectrofotométrico do ácido resínico e seus derivados, Dissertação, Revista da Faculdade de Ciências de Coimbra 11(1): 117.

6. Archives of Faculty of Sciences of Coimbra (1996) Curriculum Vitae of António Andrade de Gouveia, Coimbra.

7. Paulo Martins [2017] Organic Chemistry in Portugal from 1900 to 1970: A contribution to the history of science. Orbital: Electronic Journal of Chemistry 9(5): 363-371.

8. António de Gouveia, F Pinto Coelho (1936) Determinações quantitativas da vitamina A pelo método espectrofotométrico. Estudo de alguns óleos de fígados de bacalhau de empresas de pesca Portuguesas, Revista da Faculdade de Ciências de Coimbra 6(1): 191.

9. António de Gouveia, Karl Schön, F Pinto Coelho (1939) Determinações quantitativas de vitamina A, ergosterol, vitamina B2 (lactoflavina) e vitamina $\mathrm{C}$ por métodos físico-químicos. Estudo do vinho tinto da Bairrada, Revista da Faculdade de Ciências de Coimbra 8(1): 131.

10. António de Gouveia, F Pinto Coelho, Aires de Lima (1946) Determinações quantitativas de ácido fítico. Estudo de produtos de panificação da cidade do Porto, Revista da Faculdade de Ciências de Coimbra 15(1): 55. 
11. António de Gouveia, Alfredo Gouveia (1952) Contribuição para o estudo químico de peixes da costa Portuguesa. Carotenoides da sardinha "Pilchardus Walbaum", Revista da Faculdade de Ciências de Coimbra 21(1): 166.

12. António de Gouveia, F Pinto Coelho, Alfredo Gouveia (1953) Complexos de cobalto bivalente com ácidos resínicos. Composição e estudo espectrofotométrico, Revista da Faculdade de Ciências de Coimbra 22(1): 88.

13. Andrade de Gouveia, Grabriela Figueiredo, Abílio da Silva (1970) Métodos micro-analíticos de dosagem da plumbagina e naftoquinonas relacionadas, em soluções aquosas e meios fisiológicos. Diferenças de comportamento e meios fisiológicos, Revista Portuguesa de Química 12:104-111.

14. António de Gouveia (1934) Chromophoric groups-Part I. Ultraviolet absorption spectra of Indene and certain of its derivatives. J Chem Soc pp. 911.

15. António de Gouveia (1934) Chromophoric groups-Part II. Absorption spectra of naphthalene, hydronaphthalenes and related compounds. J Chem Soc pp. 916.
16. António de Gouveia (1976) Elogio Histórico do Professor Dr. D. António Pereira Forjaz, Memórias da Academia das Ciências de Lisboa XVIII.

17. António de Gouveia (1985) Vicente de Seabra and the chemical revolution in Portugal. Ambix 32(3): 97-109.

18. António de Gouveia (1978) Os paradigmas da afinidade química e a Faculdade de Filosofia nos fins do século XVIII, Memórias da Academia das Ciências de Lisboa, XXII, páginas p. 17-35.

19. Andrade de Gouveia (1978) Livros do século XV e XVI, sobre artes químicas e simples e drogas, nas Livrarias da Universidade e de Colégios de Coimbra, Academia das Ciências de Lisboa.

20. Andrade de Gouveia (1986) Garcia d'Orta e Amato Lusitano na ciência do seu tempo. Academia das Ciências de Lisboa 1: 335-352.

21. Andrade de Gouveia (1987) Desenvolvimento da química e das ciências relacionadas e o seu impacto com actividades científicas e culturais em Portugal, Revista Portuguesa de Química 29:127-139.

22. Manuel Rodrigues, Abílio Queirós, Luís de Almeida (1992) Memoria Professorum Universitatis Conimbrigensis, Arquivo da Universidade de Coimbra.

Your next submission with Juniper Publishers
will reach you the below assets
- Quality Editorial service
- Swift Peer Review
- Reprints availability
- E-prints Service
- Manuscript Podcast for convenient understanding
- Global attainment for your research
- Manuscript accessibility in different formats
( Pdf, E-pub, Full Text, Audio)
- Unceasing customer service
Track the below URL for one-step submission
https://juniperpublishers.com/online-submission.php

